ACTS OF NARRATIVE 
Contributors

Rachel Bowlby

Cathy Caruth

Tom Cohen

Jacques Derrida

Diane Elam

Carol Jacobs

Alan Liu

J. Hillis Miller

W.J.T. Mitchell

Ronald Paulson

Nicholas Royle

Ronald Schleifer

Dan Shen

Henry Sussman 


\section{ACTS OF NARRATIVE}

\section{Edited by Carol Jacobs}

and Henry Sussman

STANFORD UNIVERSITY PRESS

STANFORD, CALIFORNIA

2003 

For J. Hillis Miller, in celebration of his unparalleled and unrelenting insight, ethics, justice, teaching, and friendship 
Stanford University Press

Stanford, California

(C) 2003 by the Board of Trustees of the

Leland Stanford Junior University.

All rights reserved.

Library of Congress Cataloging-in-Publication Data

Acts of narrative / edited by Carol Jacobs and Henry Sussman.

p. $\mathrm{cm}$.

Includes index.

ISBN 0-8047-4650-8 (cloth : acid-free paper)

ISBN 0-8047-465I-6 (pbk. : acid-free paper)

I. English literature-History and criticism-Theory, etc.

2. American literature-History and criticism-Theory, etc.

3. Narration (Rhetoric) I. Jacobs, Carol. II. Sussman, Henry.

PR2I.A28 2003

$820.9^{\prime} 23-\mathrm{DC} 21$

2003002091

Original Printing 2003

Last figure below indicates year of this printing:

$\begin{array}{llllllllll}\text { I2 } & \text { II } & \text { IO } & 09 & 08 & 07 & 06 & 05 & 04 & 03\end{array}$

Typeset by Tim Roberts in II/13.5 Garamond 